\title{
Home Ownership, Social Costs, and Wellbeing in Self Residence: The Case of Employees of Obafemi Awolowo University, Ile-Ife, Nigeria
}

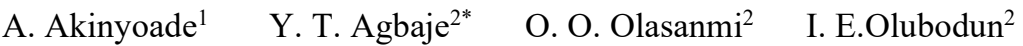 \\ 1. African Studies Centre, Leiden University, Netherlands \\ 2.Obafemi Awolowo University, Nigeria
}

\begin{abstract}
The study assessed home ownership, social costs and wellbeing in self residence in Nigeria using the employees of Obafemi Awolowo University, Ile-Ife as case study. Structured questionnaire was designed to elicit information from 279 respondents that were selected using convenience sampling method. Both descriptive and quantitative methods were employed in the analyses. The study revealed elements of economic and social dysfunctionality brought by dynamics of experiences of homeowners. This was made manifest in the form of personal provisions for water, electricity, roads, and partial completion in homes. It also manifested in the form of qualitative attributes which made it non competitive to discharge some academic responsibilities as effective as it ought to be if camp us residence were made available. Despite the challenges in terms of social costs in home ownership, the cultural orientation of Nigerians still deems it worth it to own a home. The study finally recommended an adjustment in OAU staff housing policy for academic and non-academic staff, and family sizes are getting smaller and families disperse, it behooves that new housing architectural design for housing units responding to evolving family sizes are necessary, and facilitation of Public Private Partnerships (PPPs) for the availability and affordability of public water and electricity supplies.
\end{abstract}

Keywords: appealing, costs, favouritism, home, loan, right-to-buy, selection, knock-down prices.

DOI: $10.7176 / \mathrm{EJBM} / 12-17-05$

Publication date:June 30th 2020

\subsection{Introduction}

The Sustainable Development Goals (SDGs) adopted by UN Member States as Agenda 2030 for Sustainable Development in September 2015 in New York set 17 goals with specific targets with the aim of reaching them until 2030. One of these is goal number 11, set towards the attainment of sustainable cities and communities (UNDP). Domestication of Goal 11 by regional and national entities means providing access to decent and affordable housing for all in communities which are socially, economically and environmentally sustainable and where everyone is enabled to reach their full potential (Housing Europe, 2017). Achieving SDG 11 requires a high level of commitment to create enabling conditions for affordable housing and the achievement of citizens' right to adequate housing (UN HABITAT). In Singapore, more than nine in ten Singaporeans are homeowners, a higher rate than in any other rich country. The country's first Prime Minister (Lee Kuan Yew) had argued that home ownership is essential foundation for wealth creation and that it gave ordinary people a stake in the country and its future. This Singaporean model appeared to have had some influence on Margaret Thatcher's "right-to-buy" programme in the 1980s, by allowing Britons in social housing to buy their property at knock-down prices (The Economist, 2020a).

Housing means more than a roof over heads and its significance is entrenched in Maslow's hierarchy of needs theory (Maslow, 1943). It provides a foundation for individual, family and community wellbeing and gives the owner a personal sense of place and comfort. The home is the physical space where the family is raised, and provides a setting for involvement in neighbourhood activities. Secure and affordable housing also contributes to man's social and economic wellbeing, and is central to a fair and prosperous existence (The Economist, 2020a). In the current conditions of the Covid-19 pandemic, our homes are completely critical to our health and well-being; the current crisis will change the functionality of homes as we are going to be exploring over the next couple of years a world where people spend more time at home and (even if we have a universal vaccine), with implications that the need for light space, digital and social connectivity will become even more critical (Housing Europe, 2020).

However, the Economist (January 16, 2020) views home ownership as the "horrible housing blunder", and "an obsession that undermines growth, fairness and public faith in capitalism", for several reasons. The housing system in rich countries continues to experience creeping dysfunctionality as vibrant cities emerged without space to grow; homeowners are ageing and they now occupy half-empty homes; and there is a growing generation of young people who cannot easily afford to rent or buy, now armed with a thinking that capitalism has let them down. These outcomes could be blamed on warped housing policies that date back to the Second World War and which are intertwined with an infatuation with home ownership. They have caused one of the rich world's most serious and longest-running economic failures. 
Despite huge investment in safe and affordable housing, and building resilient societies and economies as shown in Singapore, home ownership is in decline in the country. The Economist (2020a) argues that this is not a cause for concern. It is emerging therefore that despite the touted benefits of home ownership, it comes with costs that may not necessarily make it appealing as a must-have for citizens, and though home ownership is important, it is not likely a necessary condition for the attainment of the right to shelter. This has some implications for understanding the socio-economic dynamics of home ownership in countries that are experiencing housing deficits. Home ownership looks positive at the macro level; it also raises the question of social costs at the micro level in societies where severe housing deficits and urban planning is non-existent such as Nigeria. At the 2017 Housing Summit in Abuja (the country's capital), it was noted that housing deficit increased from 7 million units in 2007 to 17 million units in 2017. Housing requirement has risen to unacceptably high levels due to the unprecedented urbanisation resulting from high rural-urban migration which has created large demand for affordable housing accommodation and has given rise to slum population in the urban areas and inadequate infrastructural facilities in the rural areas (Punch, 2017). In this study, we examine the social costs of house ownership and well-being of house owners, with a special focus on employees of the Obafemi Awolowo University of Nigeria.

\subsection{Housing Policy and Practice in Nigeria}

Governance at the three tiers in Nigeria have attempted to address the issue of housing on several occasions in order to guarantee home for all, but results have not justified such attempts. For instance 601,000 housing units were planned by government between 1962 and 1995 but records show that only 77,214 housing units were achieved. This figure represents 12.85 percent (Pison Housing, 2009). Major constraints that have plagued efforts include poor continuity in government agenda, corruption in governance - exemplified in extremely negative rankings in the Transparency International annual index - which is a bane to social and economic activities among publicly handled projects in the country (Ogbeidi, 2012). Failed public housing projects dot the national landscape; and where there appears to be attempts at urban regeneration, the benefits go to the few rich, while the numbers of internally displaced persons continue to rise as previous occupiers get ejected from the geographical space. In many cases, government designed housing projects meant for civil servants and other middle and low income earners end up in total cost beyond the reach of the targeted beneficiaries (Windapo, 2000; Okupe, 2000). The resulting social and economic benefits run counter to what is expected, for example, from bank mortgage products due, to limitations on economy of scale.

Inability to address this picture shifted the attention of government at a time from housing provision to housing loan provision (NHP, 1991). Housing loan provision is a situation where government decided to give autonomy to individuals on how to decide and design location, construction, and habitation of their structure. The strategy was to make available loan facility payable over a specified tenure at minimal interest rate of about $9 \%$ (NHP, 1991). This approach also did not go without its attendant setback; targeted beneficiaries did not receive loans on time due to bureaucratic problems. When such loan eventually reached beneficiaries, its value had been eroded due to depreciation of the national currency (Akinyoade and Uche, 2017). Another fundamental problem was the favouritism in the selection of loan beneficiaries, which in turn affected loan recoveries; banks' financial strengths waned. Due to the foregoing, current day employees in Nigeria have shifted from depending on government for housing provision or loan provision by embarking on self-financed and self-construction of homes. Individuals save towards purchase of land and starting construction, which takes a long time to achieve. Work colleagues, through workplace cooperative initiatives buy acres of land, for plot redistribution to members. Such allotees pay for such parcel of land through a direct deduction from their salary over a specified period of time. Home designs eventually come with varying standards depending on income and status at work, as the construction is financed and supervised through individual initiatives.

Despite people struggle to put in their edifice according to their income capacity, status, and stage in lifecycle; social amenities such as road, water, electricity, and security needed in any residential quarter are still at the expense of these individuals. Public utilities are individually arranged and many areas lack urban planning. This study therefore attempts to examine the effect of home ownership, and social costs, on wellbeing in selfconstructed residence among employees of Obafemi Awolowo University, Ile-Ife, Nigeria. The choice of the study area is unique in the sense that the University was established with standard urban planning regulations. Both academic and administrative staff had access to university accommodation, with staff quarters in planned layouts. However, as the student population grew, especially in the 1980s, staff strength expanded, without commensurate provision of housing for increasing number of staff and students. Even for those that retire, they had to move out of university residential quarters. Serving employees that had no access to university accommodation were allowed to rent houses outside the campus. In the course of 1980s, changes crept into the university in content and structure. It had implications for social divisions among staff when those living on the campus with guaranteed housing and public services provision are compared with those who had to look for shelter and services options outside the precinct of the university. This study therefore examines the dynamics and social implications of home ownership using the experience of university staff. 


\subsection{Literature Review}

Researches have established it that the pattern of home ownership is not universal irrespective of demographic group, or regions of any country. It has also been established that income is a significant factor in home ownership (Haurin, et. al., 2007). Home ownership by a first timer faces considerable income barrier, which limits opportunity to invest in the available as opposed to buying the desirable.

Many studies on home ownership such as Warner \& Roundtree (1997) have established the importance of social benefits. This they have found that residential stability strengthens social ties with neighbours. Other researches focused on how increased mobility by way of regular change of residence diminishes the depth of social ties because there is less time to build long-term relationships. Sampson et al. (1997) argue that social cohesion and strong ties are paths through which resources for social control are made. The purported benefits of home ownership may partly arise not directly from ownership, but from greater housing stability and social ties associated with less frequent movements among home owners. According to Lindblad et al. (2013), the impact of home ownership is through collective efficacy, which is measured by specifying a new role for sense of community as social cohesion. Collective efficacy refers to the idea that a community can influence the behaviour of members of the community to promote a safe and orderly coexistent.

Green and White (1997) found that home ownership have a significant effect on children's success. The decision to stay in school by teenage students is higher for those raised by home-owning parents compared to those in renter households. Furthermore, daughters of home owners have a much lower incidence of teenage pregnancy. The authors point to certain behavioural characteristics required of home owners that get passed on to their children. First, home ownership naturally involves one of the largest financial commitments most households will undertake (Agbaje, 2020). Home owners are required to take on a greater responsibility such as home maintenance and acquiring the financial skills to handle loan repayments. These life management skills may get transferred to their children. However, the causal link between home ownership and improved schooling performance of children is not completely clear. It could be that home ownership brings residential stability, and it is the stability that raises educational attainment of such children. Such interpretation is consistent with a study by Harkness and Newman (2003) who found that, though home ownership raises educational outcomes for children, neighbourhood stability further enhanced the positive outcome. In addition, a study by Hanushek et al. (1999) showed that changing schools negatively impacts children's educational outcomes particularly for minorities and low income families. In this instance, renters with higher propensity to move will frequently change school to cope with their new location. Aaronson (2000) found that parental home ownership in low-income neighbourhoods has a positive impact on high school graduation. But he cautioned that some of the positive effects may arise due to the greater neighbourhood stability (less residential movement) and not necessarily to home ownership alone.

In another study, Haurin et al. (2001), the authors established a higher overall quality of life among home owners that is believed to contribute to the well-being of both home owners and their children in a number of ways. For example, young children of home owners tend to have higher levels of achievement in their academic comprehension and fewer behavioural problems (which often carry over into reduced deviant behaviour in later years). Better social outcomes arise as parents provide a more supportive environment for their children. These factors, as well as many others help to explain increased educational attainment and higher lifetime annual incomes of home owners' children. Research has also confirmed that access to economic and educational opportunities are more prevalent in neighbourhoods with high rates of home ownership and community involvement (Ellen and Turner, 1997). Boehm and Schlottmann (1999) show that the average child of home owners is significantly more likely to achieve a higher level of education as well as a higher level of earnings in life. The authors further concluded that the housing tenure of parents plays a primary role in determining whether or not the child becomes a home owner.

Weiss et al. (2010) proposed that home ownership provides for engaged parenting practices in two ways: economic and psycho-social. The economic impact of home ownership refers to the positive impact of nurturing neighbourhoods. While both home owners and renters may aspire to be engaged parents, home owners likely live in neighbourhoods with more opportunities for school involvement or participation in neighbourhood activities. The psycho-social component refers to the idea that being a home owner may limit the severity of economic hardships and the degree to which financial hardships result in psychosocial stress and disengaged parenting. Home owners tend to remain in their homes longer; they add a degree of stability to their neighbourhood. Studies by Rossi et al. (1996) and Rohe \& Stewart (1996) concluded that home owners also reap the financial gains of any appreciation in the value of their home. This is because home owners possess the right to transfer the property to an heir (Agbaje, 2020). On this note, they also tend to spend more time and money maintaining their residence, which also contributes to the overall quality of the surrounding community (social benefits). Renters, with less wealth tied to a specific locality have less incentive to protect the value of their residence.

\subsection{Methods and Data}

In order to attain the objectives of this study, 279 staff of the OAU, living outside the university were purposively 
sampled. The university is situated in the outskirts of Ile-Ife township. This town, with an estimated population of 400,000 people is located in Osun State (5.3 million people) in southwest Nigeria (national population 206 million) - See PopulationStat (2020a, 2020b, 2020c). Two main entry-exit points connect the university to the town. Many of the staff, residing externally the campus, are found in close proximity of the localities near the two main entrances. Such localities include Mayfair axis, Omole-Aserifa-Ajanaku estates residential, Ibadan road, Ede road, Road 7, and Fajuyi areas of the town. A questionnaire survey was conducted in these areas. The questions were designed to elicit information such as socio-economic background of respondents, employee status, current state of construction of inhabited house, factors of residence (rental or owner-occupier), as well as indicators of wellbeing and social costs of place of habitation. The results are presented in the tables below.

\subsection{Results}

\subsection{Background characteristics of respondents}

The background characteristics of respondents, measured in terms of age of house owners, and proportional distribution with regard to gender, number of years of living in their own homes, educational and working status of their children are presented in Table 1. Among the respondents sampled, three-quarters are aged above 40 years, while approximately $25 \%$ of all home owners are aged below 40 years. In other words, the older the respondent is above 40 years, the higher the chance of living in own home. This statistic compares with European data which shows that across the 12 OECD countries studied, changes in the age structure boosted homeownership rate by $3 / 4$ 1 percentage point on average (Andrews and Sanchez, 2011).

Table 1: Socioeconomic Characteristics of Home Owner Occupier Respondents

\begin{tabular}{|c|c|c|c|}
\hline \multicolumn{2}{|c|}{ Attributes and sub-classifications $($ Sample $=279)$} & Frequency & Proportion (\%) \\
\hline \multirow[t]{2}{*}{ Age of household head } & $\leq 40$ & 65 & 23.3 \\
\hline & $>40$ & 214 & 76.7 \\
\hline \multirow[t]{2}{*}{ Gender } & Male & 266 & 95.3 \\
\hline & Female & 13 & 4.7 \\
\hline \multirow[t]{3}{*}{ Marital status } & Married & 263 & 94.3 \\
\hline & Widowed & 11 & 3.9 \\
\hline & Widower & 5 & 1.8 \\
\hline \multirow{3}{*}{$\begin{array}{l}\text { Number of years living in own } \\
\text { home }\end{array}$} & $1-5$ & 54 & 19.4 \\
\hline & $6-10$ & 196 & 70.3 \\
\hline & Greater than 10 & 29 & 10.4 \\
\hline \multirow[t]{2}{*}{ Educational status of children } & In school & 163 & 58.42 \\
\hline & Schooling concluded & 116 & 41.58 \\
\hline \multirow{5}{*}{$\begin{array}{l}\text { Social status of children that have } \\
\text { completed schooling }\end{array}$} & Working (married, moved out) & 101 & 36.20 \\
\hline & Working (single, moved out) & 80 & 28.67 \\
\hline & Not working (at home) & 53 & 19.00 \\
\hline & Not working (married, moved out) & 26 & 9.32 \\
\hline & Working (at home) & 19 & 6.81 \\
\hline
\end{tabular}

Source: Field Survey, Ile-Ifę, 2019.

The finding also indicate that more than $70 \%$ of the respondents have been living in own homes for more than six years. The distribution also shows that $58.42 \%$ of respondents have children who are still in school while $41.58 \%$ of respondents have children who have completed schooling. This has implications for a possibility that having been relieved of the burden of funding their children's schooling, such home owners may use freed up resources to conduct house maintenance and upgrades, which may in turn increase the value of the property. A US study indicated that homeowners age 55 and over already generate a little more than half of all home improvement expenditures in the nation (Joint Center for Housing Studies, undated).

Homeowners whose wards have completed schooling are further analysed with regard to the post-schooling social status of their wards. Two main subcategories are observed: homeowners whose wards move out of the home after completing schooling and homeowners whose wards after completing schooling still live with homeowner. This later subcategory constitutes $35.13 \%$ of all homeowners. The incidence of young adults that have completed schooling but still living at their parents' home is rising, with increasingly negative social implications. The context was conceptualised as 'waithood' by Honwana (2014) as a period of suspension between childhood and adulthood, where a person's chronological age defines them as adults, yet, they are still unable to 
become independent adults. The majority of African youths are today grappling with a lack of jobs and deficient education. After they leave school with few skills, they are unable to obtain work and become independent to build, buy, or rent a house for themselves, support their relatives, get married, establish families and gain social recognition as adults. These attributes of adulthood are becoming increasingly unattainable by the majority of young people in Africa.

Table 2: Home ownership and occupancy status of respondents

\begin{tabular}{|l|l|r|r|}
\hline \multicolumn{2}{|l|}{ Attributes and sub-classifications } & Frequency & \multicolumn{1}{l|}{$\begin{array}{l}\text { Proportion } \\
(\%)\end{array}$} \\
\hline \multirow{2}{*}{ University work/staff status } & Academic & 160 & 57.3 \\
\cline { 2 - 4 } & Non-academic & 119 & 42.7 \\
\hline \multirow{2}{*}{ State of completion of home } & Fully completed & 113 & 40.50 \\
\cline { 2 - 4 } & Partially completed & 166 & 59.50 \\
\hline \multirow{2}{*}{$\begin{array}{l}\text { Reasons for not using on- } \\
\text { campus staff residence }\end{array}$} & Allocation unavailable & 170 & 60.9 \\
\cline { 2 - 4 } & Freedom to design own house & 19 & 28.3 \\
\cline { 2 - 4 } & Desire for own building before retirement & 11 & 6.8 \\
\cline { 2 - 4 } & Fear expulsion order by campus authorities & & 3.9 \\
\hline
\end{tabular}

Source: Field survey, 2019.

The employment status of the respondents surveyed indicates that about $60 \%$ of them are academic staff while the remaining are non-academic staff. The non-academic staffs include employees in various administrative, service and support roles. The homes they own and occupy are $40.50 \%$ fully completed while $59.50 \%$ are in different stages of completion. The incompleteness are noted as, for example, having not plastered the internal walls and floors, incomplete kitchen (thus opting to cook in tripod charcoal stove outdoors), low height of or absent compound wall, and others.

Exactly three-fifth of respondents indicated that the decision to take occupancy was because they have no housing allocation made available for them on campus; about $30 \%$ preferred living in their own homes outside the university because it gives them the freedom to design their own place of abode based on personal taste (Table 2). On campus, residential housing allocated to staffs are of the same design. A few others also prefer to live off campus because it allows them to get used to the place they will live after retiring from university service. This will also equip them with high neighbourliness that would be difficult to cultivate at a too old age after retirement. It is imperative for staff to move out of campus housing, after retirement; six months is the maximum duration of stay in campus housing after retirement or after the death of the main employee in the household. Another reason indicated by respondents was the fear of ejection order by government, especially if university staff embarked on industrial action. This fear dates back to the mid-1990s when the military head of state, General Sani Abacha, gave university staff a short notice to vacate their quarters due to a strike action. In a period spanning March to October 1996, university teachers went on strike to demand for adequate and increased salaries and other working conditions (Idachaba, 2001). In return, the military government banned their association; the Academic Staff Union of Universities (ASUU) and proceeded to announce ejection from staff quarters that threw a lot of staff into disarray.

\subsection{The social costs of homeownership outside the university}

The concept of social costs in this study refers to those categories of situations that do not present the accommodation to be in the best position for the comfort of the owner. Some ought to be provided by government authorities, while individuals are expected to tap from the public supplies of these costs to the tune of their need at individual or household limit. Others may have to be borne at individual or community level. These costs have been classified into two in this study; real cost (quantifiable) and social cost. Real costs refer to those cost classifications that have values placed on them while social costs are those sacrifices that must be put in place in order to get the system going. Living in own-home outside the university premises comes with different social commitments to the community in which the employee has the abode. These commitments which are shared with neighbours and other members of the community are presented below in Table 3. 
Table 3: Shared social costs in locality of residence

\begin{tabular}{|c|c|c|}
\hline Community construction attributes & Frequency* & Proportion (\%) \\
\hline Painting & 242 & 86.7 \\
\hline Fence & 175 & 62.7 \\
\hline Floor tiling & 139 & 49.8 \\
\hline Control of erosion and flooding of compound & 104 & 37.3 \\
\hline Well/borehole (water provision) & 75 & 26.9 \\
\hline $\begin{array}{l}\text { Dissatisfaction: } \\
\text { (a) Poor state of roads } \\
\text { (b) Commuting time to work } \\
\text { (c) Incompatibility with neighbours social status } \\
\text { (d) Insecurity }\end{array}$ & $\begin{array}{l}211 \\
249 \\
193 \\
258\end{array}$ & $\begin{array}{l}75.6 \\
90.2 \\
69.2 \\
92.5\end{array}$ \\
\hline
\end{tabular}

Source: Field survey, 2019. Note: * multiple response questions

Despite the fact that nearly one-third of Staff living in own-residence off-campus expressed that freedom in designing their own houses was a motivating factor in their decisions, certain housing construction attributes weigh on their off-campus abode. Large proportions $(86.7 \%)$ of all respondents have to consider painting styles as a cost that may increase their expenses. This arises from comparisons made with regard to externally observable aesthetics, and/or internal finishing and fashion modes observed during moments of visits and closer interactions with neighbours on occasions of social visits (birthday, child naming, wedding, religious ceremonies and the like). The quality and style of materials deployed for painting, floor tiling, and internal décor observed during visits appear to often influence choices made by other houseowners. Differentials in choice and quality are reflective of houseowners economic power, social class and network of interaction. This type of influence is minimal in campus accommodation given the similarity or monotony of the design of staff quarters.

But many of the academic staffs sampled in this study are not enthused with the factor of commuting time to work. Those who are in the natural sciences sometimes run laboratory experiments that may warrant taking readings at periodic intervals over several days. Returning to laboratories and project sites at mandatory intervals is inconvenient for such staffs that live off campus, and cannot commute especially in the curfew/locked campus gate hours 2300-0600 hours. These stated reasons impair academic endeavour. The advantage is more for oncampus staff who can visit their offices and laboratory sites at will. Added to this is the parlous state of access to public water supply, which necessitated at least one-quarter of all respondents to individually procure water supplies from privately dug boreholes in their compounds. Experience in urban water utilities in developing countries has shown their limitations because of weak regulatory regimes compounded by inherent problems of information, incentives, and commitment (Araral, 2008). Without public water connections, homeowners have resorted to baseline investments in digging boreholes for accessing fresh water supply. Other homeowners rely on unprotected wells and springs, the shallow levels of which compromises water quality due to surrounding sources of contamination. In a similar fashion, such homeowners also make baseline investments in power access. Where direct access to public electricity is not available, homeowners invest in purchase of private power generators. Even where public power exists, regularity of supply is not assured. Therefore, homeowners still invest sums of money into acquiring power generators. On campus, electricity supply is relatively more stable; although, many staff residence occupiers still buy generators to supplement the irregular power supplies.

Respondents also reported disaffection with the poor state of connecting roads, incompatibility with neighbours' social status, increased commuting time to work as well as insecurity. Attempts to mitigating the disillusionment are made by respondents who incur personal financial costs and/or contribute to communal donations that are gathered for provision of public utilities where they are absent. For instance, the baseline investments sourcing water from a borehole is priced at $\$ 450,000$ (approximately $€ 1000$ ). This includes the borehole, main water stand, water tank, and a pumping machine. For the water pumps to work and to have electricity in the house for other uses, another baseline investments is recorded at $\$ 300,000$ (approximately $€ 700$ ). Contributions for electricity connection to the locality added on, in many cases for public connection include monies for electric poles (connecting cables to public grid, connection wires and cables, and purchase of metre on which the public official can read and estimate charges for payment to the public electricity company). Other equipment is the ubiquitous set generating set, which in itself, has to be powered by gasoline or diesel fuel. These fuels and lubricating oils are subsequent regular expenses that have to be borne by the user. Societally, the homeowner must pay monthly contributions for maintenance of communal security outfits; routine weeding and clearing away of overgrown bushes in the community, maintenance of access roads, and in some cases contributions are made to the public health centres in the vicinity. 
Table 4: Significant servicing investments and contributions to urban regeneration

\begin{tabular}{|c|c|c|}
\hline Service items & Description & $\begin{array}{c}\text { Costs (Estimate) } \\
\text { ( })\end{array}$ \\
\hline Water provision (borehole, water stand, water tank, pumping machine) & \multirow{2}{*}{$\begin{array}{l}\text { Baseline } \\
\text { investment }\end{array}$} & 450,000 \\
\hline $\begin{array}{l}\text { Public and private electricity (purchase of electric pole, generating set, } \\
\text { electricity connection cables, electricity consumption metres) }\end{array}$ & & 300,000 \\
\hline Security (Day \& night shifts) & \multirow{4}{*}{$\begin{array}{l}\text { Annual } \\
\text { expenses }\end{array}$} & 24,000 \\
\hline Routine clearing of bushes in the locality & & 15,000 \\
\hline Road construction (contribution to community purse) & & 5,000 \\
\hline Health \& maternity centre & & 5,000 \\
\hline
\end{tabular}

Source: Primary data, Ile-Ifę, 2019.

Access roads to localities and communities are in serious state of disrepair in Nigeria. The country "has a fairly extensive infrastructure of roads, railroads, airports, and communication networks. The road system is by far the most important element in the country's transportation network, carrying about 95 percent of all the nation's goods and passengers. Currently, many of the roads are in disrepair because of poor maintenance and years of heavy traffic." In the community of focus, dusty atmosphere prevail during the dry season (November-April) and un-motorable muddy roads are sometimes experienced in the raining season (May-October). In order to ameliorate road conditions, residents contribute money for basic road maintenance (hiring of a grader to level the soil). Pedestrians carry extra pairs of shoes in their bags as they navigate extensive puddles. Proper drainage and bitumen layer seems the obvious solution to the perennial problems but several roads remain unattended to by administrative authorities.

Contributions to the communal pool for undertaking publicly shared spaces are managed by a Community Chairperson. In most cases, the position is held by a man, and it does not connote that this person has the best house or be the richest person in the community. However, the position holder has the time and clout to go after erring contractors, and solve conflicts that may arise from community members at the time contributions are made.

\subsection{Social Paradigm in Home Construction}

Almost all formal workplaces in Nigeria of today including Obafemi Awolowo University Ile-Ife are involved in an organised saving arrangement called cooperatives where members save a pre-indicated and convenient amount of money to meet certain obligations. These regular savings are deducted from source before payment of net balance (Agbaje \& Lawal, 2013). This arrangement is such that any member can pool out three times the amount in his/her account with the cooperative any time the need for some routine investment arises. On the contrary, what is paid into the cooperative after loan had been sourced no longer becomes convenient, rather 'neck twisting' that must be fully paid back at the limit set by cooperative regulations (between 24 to 30 months). However, for control purposes and to erase or minimise corruption at duty post level, each person is not permitted to have deductions in his/her account higher than two-thirds of pay; leaving out one-thirds for self and family consumables. With an average monthly saving in the pre-loan period of approximately $\$ 30,000$ in an economy where it costs approximately $\$ 5.92$ million (excluding land acquisition) to build three bed room self contain (Agbaje, 2020), loan acquisition could stretch to three to four times, with each payback period of 24 to 30 months, and a monthly deductible amount of about $\$ 80,000$ depending on how much the individual applied for, but it is certain that every loan applicant for building will apply for the maximum. Complete payback of a loan marks the earliest time that another application can be made. This periodic loan for house construction also impinges on other social and family responsibilities (school fees, feeding, clothing, and other general welfare). In summary, it takes about eight years on average to complete a three bedroom bungalow. This is even in the face of a non-challenging financial appropriation such as health of family member or other dependents.

Going by the statistics at the university housing allocation committee, there are about 498 staff apartments and are all fully allocated within the staff quarters without any expansion in housing provision on the campus since 1985 when the Buhari-Idiagbon military regime suspended all capital projects by Federal Government in the country. On this note, the ever increasing staff population that has increased to over 3,500 leaves more than 3,000 of the employees to arrange for accommodation outside the campus. 
Table 5: Relationship Between Social Obligations and Sustainable Housing Provision

\begin{tabular}{|l|c|c|}
\hline \multirow{2}{*}{ Social obligations } & Difficulty in achieving goals at t & Arrears t \\
\cline { 2 - 3 } & \multicolumn{2}{|c|}{ Figures in cells are in percentages } \\
\hline Difficulty in face-lifting the state of house t-1 & 59.8 & 31.5 \\
\hline Difficulty in face-lifting the state of house t & -- & 43.9 \\
\hline Accumulation of target t-1 & 74.3 & 48.3 \\
\hline Accumulation of target t & 100.0 & -- \\
\hline Low income t-1 & 27.5 & 23.3 \\
\hline Low income t & 24.7 & 11.1 \\
\hline Entered low income between period t-1 to t & 24.8 & 9.8 \\
\hline Zero saving at period t-1 & 19.9 & 21.5 \\
\hline Zero saving at period t & 14.7 & 8.8 \\
\hline Stopped saving at period t-1 & 5.0 & 6.3 \\
\hline Retired since period t-1 & 25.3 & 9.4 \\
\hline Retired at period t & 18.4 & 6.7 \\
\hline
\end{tabular}

Source: Primary fieldwork, Ile-Ifę, 2019

Table 6: Incidence of Sustainable Housing and the number of Haves in Household Items

\begin{tabular}{|l|c|c|}
\hline \multirow{2}{*}{ Number afforded t } & Difficulty in achieving goals at t & Arrears t \\
\cline { 2 - 3 } & \multicolumn{2}{|c|}{ Figures in cells are in percentages } \\
\hline 0 & 1.7 & 0.6 \\
\hline 1 & 3.2 & 1.1 \\
\hline 3 & 5.4 & 2.4 \\
\hline 4 & 14.6 & 6.9 \\
\hline 5 & 35.3 & 20.4 \\
\hline
\end{tabular}

Source: Primary fieldwork, Ile-Ifę, 2019

Affordable items are: automobile, replacement of worn-out furniture, electronics, new clothes, balanced meal to taste

\subsection{Impact of social Costs on Sustainable Housing Commitment}

Sustainable housing commitment is the ability of household heads to commence any aspect of a building and being able to implement it wholly without the interference of any other household social commitments from the same source of income. However, growth of children and other dependents in their career advancement rests heavily on the almost constant or even ever reducing income in real terms due to high inflation rate. For instance, Nigeria is forecasted to suffer eight straight years of diminishing Gross National Income per capita (Runsewe, 2018)

In order to establish the relationship between social costs and other measures of household financial position, a correlation comparison was conducted (Table 5). This was done using a range of other family commitments. It is observed that about $60 \%$ of those who had difficulty in achieving goals set for period t-1 (last year) also had difficulty in achieving goals set for period $t$ (current time). Also, about three-quarters of those in arrears (accumulation of target) indicated persistent difficulty in sustainable housing provision. This persistent difficulty was also illustrated by households that entered low income last year $(27.5 \%)$ retired from their job last year $(25.3 \%)$. With these statistics, it can be concluded that financial shocks is a causal agent in sustainable housing commitments. As far as house infrastructure maintenance is concerned, there is high incidence of persistent difficulty in achieving this set target ranging from $31.5 \%$ in the previous period to $48.3 \%$ in the current period. A close look at Table 5 also depicts that $43.9 \%$ of respondents in housing maintenance have experienced lengthy delays. Persistent difficulty in repairing spoilt or deficient parts of the house are reported by respondents that were in low income $(24.7 \%)$ or who entered low income since previous period $(27.5 \%)$, but not so strong for the category that have just retired from the service of the university $(18.4 \%)$.

Additional results as presented in Table 6 indicated that the ability of home owners to afford some items has an inverse relationship on sustainable housing commitment. Thus, basic needs must be traded off in order to have an improvement of sustainable housing improvement. The data presented shows that sustainable housing development is inversely correlated with availability of some items for the comfort of the household members.

\subsection{Conclusion and Recommendations}

The preceding analyses have revealed elements of economic and social dysfunctionality brought by dynamics of experiences of homeowners. The implications are many for current homeowners, tenants, and future buyers. A fresh architecture is urgently needed for a revamping of the housing economy if goal 11 of the sustainable agenda 
is to be realized and right to shelter for citizens actualized. Investing in affordable housing equals investing in sustainable development, which in itself cannot be achieved without significantly transforming the way urban spaces are built and managed. Making cities also means creating career and business opportunities, investment in public transport, creating green public spaces, and improving urban planning and management in participatory and inclusive ways. But, at the turn of the $21^{\text {st }}$ century, the rapid growth of cities - a result of rising populations and increasing migration - has led to a boom in mega-cities, especially in the developing world, and slums are becoming a more significant feature of urban life, with attendant impact on the lucky few that own homes. The Economist (2020) argues that if planning rules are modified in just three big cities of the United States - New York, San Francisco and San Jose - national GDP will increase by $4 \%{ }^{1}$

Primary data collected for this study has shown that a good number of homeowners whose wards have completed schooling still have the same wards sharing the same living space. The inability of such wards to secure decent jobs as young adults has prevented them from leaving home to secure accommodation elsewhere. Such living conditions have negative social implications referred to as waithood. If projected at a national scale, it has significant ramifications for law and social order as Honwana (2013) noted: Youth in Africa face unemployment and restricted opportunities, driving many of them to challenge the status quo and contest socioeconomic policies and governance strategies that exacerbate poverty, heighten social inequalities, and deny them basic freedoms. Young people have emerged as active social agents in the uprisings in Tunisia, Egypt, and Libya, in the 'Y'en a Marre' movement in Senegal, and in the food riots in Mozambique, counteracting the notion that youth are apathetic. Individuals experiencing waithood have been termed in various ways as 'youthman' (Abdullah, 1998), 'kidults, adultolescents and thresholders' (Apter, 2001), 'freeters (furītā) and parasaito shinguru (single parasites) (see Miyamoto 2004, Kosugi, 2006), and the sarcastically denoted Italian 'bamboccioni (big dummy boys)'. In October 2007, Tommaso Padoa-Schioppa, then Minister of Economy and Finance, spoke to a parliamentary committee about the government's plan for tax relief (approximately $€ 500 /$ year) to people 20-30 years old, especially males, who were still living with their family, saying it would help them move out on their own. He used the ironic or sarcastic term bamboccioni. Many Italians found the term offensive because in their opinion the problem is not the youth themselves but rather the system. A substantial number of young Italians live on approximately $€ 1,000$ per month and cannot afford to leave their parents' house (Honwana, 2014).

With regards to access to public utilities, this study has shown a high relative lack of access to public water supply that homeowners suffer. In spite of the importance of adequate water quality and quantity for human health and survival, public water supply coverage in Nigerian cities appears to be decreasing and deteriorating. Hence, this study was designed to assess the challenges of public water provision in Nigerian cities. Some of the reasons for this deterioration include: inadequate water supply policy, lack of autonomy for the various State Water Agencies (SWAs), corruption in the water sector, poor infrastructure investment and maintenance, deficiencies in pipe distribution networks and inadequate power supply (Ohwo, 2016). Deficiencies in local governance ability to ensure available and affordable public utilities have resulted from the half-hearted attempts at decentralization of governance. Unfortunately, the lack of baseline finance to carry out devolved functions has continued to contribute to plague public service delivery, hence the resort of citizens to private provisioning in order to plug the gap.

At a more practical level is what these finding means for the efficient and sustainable reduction of the huge housing deficits in Nigeria, bearing in mind that the housing policy will undoubtedly have implications for unintended social and economic outcomes. From the data collected, it is evident that a clear re-structuring of urban planning rules are needed in Nigeria, as symbolized by analysis of home ownership patterns of the OAU staff; the positive implications of this for economic growth becomes obvious on a national scale.

Therefore, the following recommendations are proffered.

i. $\quad$ OAU staff housing policy adjustment for academic and non-academic staff

ii. Implication for home ownership beyond the confines of OAU working \& geographic sphere. As family sizes are getting smaller and families disperse, it behooves that new housing architectural design for housing units responding to evolving family sizes are necessary. At the same time, the new housing designs will integrate needs for space to accommodate revolving visiting members in the social ecosystem of extended families. This has implications for the optimization of land space, use and tenure for home owners.

iii. Deficiencies in the provisions of public utilities can be minimized with the encouragement and facilitation of Public Private Partnerships (PPPs) for the availability and affordability of public water and electricity supplies. The willingness to pay is signified by respondents' investment in private provisioning in this study.

\section{References}

Aaronson, D. (2000). A Note on the Benefits of Homeownership. Journal of Urban Economics, 47 (3), 356-369. Abdullah, I. (1998), Bush path to destruction: The origin and character of the Revolutionary United Front/Sierra

\footnotetext{
1 The Economist, 2020 , Home ownership is the West's biggest economic-policy mistake, January $16^{\text {th }} 2020$ Edition, Leaders, https:/www.economist.com/leaders/2020/01/16/home-ownership-is-the-wests-biggest-economic-policy-mistake Accessed May 6, 2020
} 
Leone. Journal of Modern African Studies 36(2): 203-234.

Agbaje, Y. T., \& Lawal Q. A. (2012). Social Dimensions of Employees in Formal Workplace Environment in Nigeria: Case of Cooperatives Societies in Obafemi Awolowo University, Ile-Ife, Nigeria. AAU Journal of Management Sciences, 3 (2), 105-129.

Agbaje, T. (2020). Economic Analyses of Residential Properties Among Private Investors in Ile-Ife and Its Environs, Nigeria. The International Journal of Business and Management, 8(3), 237-244

Akinyoade, A. \& Uche, C. (2017). Development built on crony capitalism? The case of Dangote Cement,

Business History, PP 1-27. DOI:10.1080/00076791.2017.1341492

Andrews, D. \& Aida C. S. (2011). The Evolution of Homeownership Rates in Selected OECD Countries: Demographic and Public Policy Influences", OECD Journal: Economic Studies, 1. http://dx.doi.org/10.1787/eco_studies-2011-5kg0vswqpmg2

Apter, T. (2001), Myth of maturity: What teenagers need from parents to become adults. New York: W.W. Norton. Araral, Eduardo. (2008). Public Provision for Urban Water: Getting Prices and Governance Right. Governance. 21, 527 - 549. 10.1111/j.1468-0491.2008.00412.x.

Boehm, T.P., \& Schlottmann, A. M. (1999). Does Home Ownership by Parents Have an Economic Impact on Their Children? Journal of Housing Economics, 8(3), 217-232.

Chionuma, N. (2000). The Role of Primary Mortgage Institutions in the Provision of Housing in Nigeria. National workshop Organised by Nigerian Institute of Quantity Surveyor. Abuja.

Ellen, I. G. \& Turner, M. A. (1997). Does Neighbourhood matter? Assessing recent evidence. Housing Policy Debate, 8(4), 833-866.

Green, R. K., \& White, M. J. (1997). Measuring the Benefits of Homeowning: Effects on Children. Journal of Urban Economics 41(3), 441-461.

Hanushek, E. A., Kain, J. F., \& Rivkin, S. G. (1999). The Cost of Switching Schools.

Harkness, J., \& Newman, S. J. (2003). Effects of Homeownership on Children: The Role of Neighbourhood Characteristics and Family Income.

Haurin, D. R., Herbert, C. E., \& Rosenthal, S. S. (2007). Homeownership Gaps Among Low-Income and Minority Households. Cityscape, 5-51

Honwana, A. (2014). 'Waithood': Youth Transitions and Social Change. In, Koninklijke Brill NV, leiden, 2014 doi 10.1163/9789004269729 004

Honwana, A. (2013). Youth, Waithood, and Protest Movements in Africa. International African Institute. https://gsdrc.org/document-library/youth-waithood-and-protest-movements-in-africa/ Accessed May 8, 2020

Housing Europe, (2020). Housing2030 - Time to Think (and do!) Differently, Brussels, 20 April 2020 | Published in Urban, Economy, Social http://www.housingeurope.eu/resource-1413/housing2030--- time-to-think-anddo-differently Accessed May 6, 2020

Housing Europe, (2017). Housing and the Sustainable Development Goals. How Housing Europe members deliver their share. Brussels, 3 October 2017 | Published in Urban, Social. http://www.housingeurope.eu/resource997/housing-and-the-sustainable-development-goals Accessed May 5, 2020

Idachaba, E. (2001). Chronology of Major Political Events in the Abacha Era (1993-1998). In, 'Kunle Amuwo, Daniel C. Bach, Yann Lebeau, Nigeria During the Abacha Years (1993-1998). IFRA Nigeria. Pp 341- 363

Joint Centre for Housing Studies of Harvard University. Demographic Change and the Remodeling Outlook.

https://www.jchs.harvard.edu/sites/default/files/harvard_jchs_2017_remodeling_repor t_chap2.pdf Page 6 . Accessed May 8, 2020

Kosugi, K. (2006). Changes in transitions from school to work: Employment behavior and transitions of youth in metropolitan areas. Japan Institute for Labour Policy and Training (JILPT), Research Report, no. 72.

Lindblad, M. R., Manturuk, K. R., \& Quercia, R. G. (2013). Sense of community and informal social control among lower income households: The role of home ownership and collective efficacy in reducing subjective neighbourhood crime and disorder. American Journal of community psychology, 51(1-2), 123-139.

Maslow, A. H. (1943). A Theory of human motivation. Psychological Review. 50(4): 370-396.

Miyamoto, M. (2004). Shakaiteki haijo to jyakunen mugyo: Igirisu to Sue den no taio (Social exclusion and youth non-employment: The responses of the UK and Sweden). Nihon Ro do Kenkyu Zasshi 533: 17- 26.

Ogbeidi, M. M. (2012). Political Leadership and Corruption in Nigeria Since 1960: A Socio-economic Analysis. Journal of Nigeria Studies. 1(2), 3.

Ohwo, O. (2016). Challenges of public water provision in Nigerian cities: a review. Journal of Water, Hygeine, and Sanitation for Development. 6 (1): 1-12.

Okupe, L. (2000). The Role of Private Sector in Housing Delivery in Nigeria. A Seminar Paper on Effective Approach to Housing Delivery in Nigeria. Organised by Nigerian Institute of Building. Ibadan.

Pison Housing Company (2009). In - EFInA and FinMark Trust (2010) Overview of the Housing Finance Sector in Nigeria. Publication commissioned by Enhancing Financial Innovation and Access (EFInA) and Making Financial Market Work for the Poor (FinMark Trust). 
PopulationStat, (2020a). Ife, Nigeria Population. https://populationstat.com/nigeria/ife Accessed May 8, 2020

Population.city, (2020b). Osun Population. http://population.city/nigeria/adm/osun/ Accessed May 8, 2020

PopulationStat, (2020c). Nigeria Population. https://populationstat.com/nigeria/ Accessed May 8, 2020

Punch, 2017, Nigeria's Housing Deficit Too High - Osinbajo, September 26, 2017, https://punchng.com/nigeriashousing-deficit-too-high-osinbajo/ Accessed May 5, 2020

Rohe, W. M., \& Stewart, L. S. (1996). Homeownership and neighborhood stability. Housing Policy Debate, 7(1), 37-81.

Rossi, P. H., \& Weber, E. (1996). The social benefits of homeownership: Empirical evidence from national surveys. Housing policy debate, 7(1), 1-35.

Runsewe, O. (2018). Weekly Economic Index: Nigeria's Income Per Capita Will Be Gloomy for the Next Five Years, Oil Prices Fall After Record Rise. http://venturesafrica.com/weekly-economic-index-oil-price- fallsback-down-after-record-rise/ Accessed May 10, 2020

Sampson, R. J., Raudenbush, S. W., \& Earls, F. (1997). Neighborhoods and Violent Crimes. Science 277, 918924.

Taylor, M., Pevalin, D., \& Todd, J. (2006). The Psychological Costs of Unsustainable Housing Commitments; Institute for Social and Economic Research Working Paper, 2006-2008. Colchester: University of Essex.

The Economist $\left(2020^{\mathrm{a}}\right)$. Home Ownership is in decline, https://www.economist.com/specialreport/2020/01/16/home-ownership-is-in-decline Accessed May 5, 2020

The Economist $\left(2020^{b}\right)$. Home ownership is the West's biggest economic-policy mistake, January $16^{\text {th }} 2020$ Edition, Leaders, https://www.economist.com/leaders/2020/01/16/home-ownership-is-the-wests- biggesteconomic-policy-mistake Accessed May 6, 2020

UN HABITAT, The Right to Adequate Housing, United Nations Fact Sheet No. 21 (Rev. 1), https://www.ohchr.org/documents/publications/fs21_rev_1_housing_en.pdf Accessed May 5, 2020

United Nations Development Programme, Sustainable Development Goals, Goal 11: Sustainable Cities and Communities. $\quad \mathrm{https}$ ://www.undp.org/content/undp/en/home/sustainable-development-goals/goal-11sustainable-cities-and-communities.html Accessed May 5, 2020.

Warner, B. P., \& Roundtree, P. W. (1997). Local social ties in a community and crime model: questioning the systematic nature of informal social control. Social Problems, 44(4), 520-536.

Windapo, A. (2000). Constrain of the Construction Industry in an Unstable Economy. A seminar paper on Effective Approach to Housing Delivery Organised by Nigerian Institute of Building. Ibadan. 